\title{
The demand trend of Italian agritourism
}

\author{
Y. Ohe ${ }^{1} \&$ A. Ciani ${ }^{2}$ \\ ${ }^{I}$ Department of Food and Resource Economics, Chiba University, Japan \\ ${ }^{2}$ Department of Economics and Food Sciences, \\ University of Perugia, Italy
}

\begin{abstract}
The demand side for agritourism in Italy has not been fully investigated despite the relatively high number of studies of the supply side. Thus, this paper statistically examined the trends in the demand side for agritourism in Italy in comparison with tourism demand in general, such as that for hotels. Data were obtained from 'Annuario Statistico Italiano', edited and issued by ISTAT (Istituto Nazionale di Statistica). Data from 1997 were compared with those from 2006. We examined the regional characteristics and trends in the composition of domestic and inbound tourists in relation to agritourism. The results are as follows. (1) Agritourism experienced rapid growth in the number of beds available and of those tourists who stayed overnight during the last decade, while the operation rate of agritourism is much lower than that of tourism in general. (2) Region-wise, the central region accounts for a large portion of agritourism demand and the southern region had the largest growth rate, while more than half of tourism demand in general went to the north in the case of hotel demand. (3) The market for agritourism domestic demand accounted for more than half of the total agritourism demand. The remaining demand was filled by inbound tourists from European countries. Among inbound European tourists, tourists from Scandinavia, UK and Germany increased sharply and therefore these inbound tourists are driving the growth of agritourism in this country. Even if we consider the particular reasons for low barriers to travel in Europe, such as the availability of land routes, a common currency with no risk presented by exchange rates, etc., these findings clearly indicate that it is essential for the development of agritourism to count not only on domestic, but also inbound tourists to raise the operation rate.
\end{abstract}

Keywords: agritourism in Italy, tourism demand, domestic and inbound tourism. 


\section{Introduction}

Agritourism in Italy has experienced remarkable development since the inauguration of the national legal framework for agritourism in 1985. Although studies on agritourism have been hitherto conducted by mainly focusing on the supply side (Ohe and Ciani [7-9], Velázquez [11]), comprehensive studies on the demand side have been scant, probably due to data constraints. Tourism studies from the aspect of demand in Italy indicate that local cuisine, including wine, is among the attractions most favored by tourists in Italy (Baloglu and Mangaloglu [1], Baloglu and McCleary [2], Getz and Brown [3]). In contrast, as a negative factor in Italy, the effects of earthquakes on tourism were evaluated by Mazzocchi and Montini [6]. Peypoch [10] disclosed the relative high productivity of the tourism industry in general in Italy.

The data on the demand side for agritourism has recently become available through official government statistics and has enabled us to investigate the demand side as well as the supply side. Therefore, this paper focuses on recent trends in demand for agritourism in Italy by taking into account supply side trends and examines demand characteristics, local distinctiveness, and features of inbound tourists in comparison with those of tourism in general. Then we attempt to clarify the issues for the future and implications related to agritourism in other counties.

\section{Data and methodology}

We obtained data from the most comprehensive official statistics, i.e., Annuario Statistico Italiano (ASI), which is annually edited and issued by ISTAT, the National Institute of Statistics. ASI provides data that show socio-economic trends in the Italian society. Data on agritourism have been recorded in the section on tourism (chapter 18) since the 1998 issue that reported on region-wise surveys made in 1996, such as the number of beds in tourist facilities, etc (ISTAT [5]). The demand data that we used included the number of inbound tourists and overnight stays on a region-wise basis beginning in the 1999 issue that contained data collected in 1997. We used the data surveyed from 1997 to 2006 because both regional demand and supply side data are available for this period. In the case of Japan and China, however, due to the lack of data for 2005 and 2006, we compared data between 1997 and 2004 instead of between 1997 and 2006.

Before exploring demand, we first look at supply side trends in agritourism in comparison with those of Italian tourism markets in general and characterize agritourism in Italy. Then, we explore the demand aspects by focusing on the significance of agritourism in the Italian tourism markets, its regional characteristics and its share of inbound tourists. Finally, we suggest policy recommendations for the development of agritourism. 


\section{Results}

\subsection{Supply side}

We briefly look at the trend in the supply side for agritourism. Table 1 shows the region-wise percentage of share of beds in various types of accommodations: the north accounted for more than half of the share of hotel beds, indicating a high regional concentration. Although the total number of beds in hotel accommodations in all of Italy increased 1.2 times in the latest decade, the percentage of beds in hotel accommodations dropped sharply from 50\% in 1997 to $31.7 \%$ in 2006. This is because of the increase in other types of accommodations in the same period. Table 1 indicates the regional share of nonhotel accommodations such as room or apartment rentals; the north accounted for two thirds of this type of accommodation, showing a higher concentration of this type of accommodation in the north than that of hotels. The number of beds in these non-hotel accommodations increased sharply, 2.6 times, from the previous decade, raising the share of non-hotel beds to nearly $10 \%(9.2 \%)$ of the total number of provided beds.

Table 1: $\quad$ Change in number of beds in various types of accommodation and regions from 1997 to 2006 .

\begin{tabular}{|c|c|c|c|c|c|}
\hline Types of accommodation & Region & 1997 & 2006 & $06 / 97$ & $\begin{array}{c}\text { Regional share } \\
\text { in } 2006(\%)\end{array}$ \\
\hline \multirow{6}{*}{ Hotel } & North & $1,024,880$ & $1,120,114$ & 1.1 & 53.7 \\
\hline & Central Italy & 350,149 & 422,325 & 1.2 & 20.2 \\
\hline & Tuscany & 152,702 & 184,288 & 1.2 & 8.8 \\
\hline & South & 397,067 & 544,503 & 1.4 & 26.1 \\
\hline & Whole Italy & $1,772,096$ & $2,086,942$ & 1.2 & 100.0 \\
\hline & $\begin{array}{l}\% \text { Share of } \\
\text { total no. beds }\end{array}$ & 50.0 & 31.7 & 0.6 & - \\
\hline \multirow{6}{*}{ Room/apartment rental } & North & 111,423 & 400,312 & 3.6 & 66.0 \\
\hline & Central Italy & 95,207 & 150,936 & 1.6 & 24.9 \\
\hline & Tuscany & 22,980 & 55,026 & 2.4 & 9.1 \\
\hline & South & 22,732 & 55,233 & 2.4 & 9.1 \\
\hline & Whole Italy & 229,362 & 606,481 & 2.6 & 100.0 \\
\hline & $\begin{array}{l}\% \text { Share of } \\
\text { total no. beds }\end{array}$ & 6.5 & 9.2 & 1.4 & - \\
\hline \multirow{6}{*}{ Agritourism } & North & 23,571 & 51,711 & 2.2 & 33.3 \\
\hline & Central Italy & 23,490 & 76,194 & 3.2 & 49.1 \\
\hline & Tuscany & 14,275 & 45,199 & 3.9 & 29.1 \\
\hline & South & 7,037 & 27,202 & 3.2 & 17.5 \\
\hline & Whole Italy & 54,098 & 155,107 & 2.9 & 100.0 \\
\hline & $\begin{array}{l}\% \text { Share of } \\
\text { total no. beds }\end{array}$ & 1.5 & 2.4 & 1.5 & - \\
\hline
\end{tabular}

Source: Annuario Statistico Italiano, ISTAT 
In contrast to the supply side features of hotel and non-hotel accommodations, the share of beds in agritourism facilities was only $2.4 \%$ of the total number of tourism facilities in 2006. However, the number of beds in agritourism greatly increased, that is, 2.9 times, from 1997 to 2006. Although the number of beds in hotels in all of Italy slightly expanded, i.e., 1.2 times, there was no large difference in expansion between regions. However, in agritourism, there was a difference between regions. While the rate of increase was the largest in the south along with central Italy, the share was still small. While the number of beds was almost identical between the north and central Italy in 1997, there was a larger increase in central Italy both in the number of beds and share of total beds from agritourism from 1997 to 2006.

To summarize, although agritourism accounted for only a small percentage of the number of beds among accommodation facilities, it is characterized by a higher rate of increase and a greater regional concentration than that of hotels. Thus, it is safe to say that agritourism has been a growing sector in the Italian domestic tourism market in the last decade.

\subsection{Demand side}

\subsubsection{Regional demand, types of accommodation and domestic demand}

Here we examine demand side aspects. Tourism statistics in Italy, including ASI, include data on the number of arrivals and departures on the demand side. When we compared the data between 1997 and 2006, we noted larger differences among accommodation facilities than in the supply side. Facility-wise, hotels accounted for nearly $70 \%$ of the share of total accommodation demand in terms of the number of departures, which means that hotels remain the principal market for accommodation demand in this country (Table 2). Region-wise, the north accounted more than half of the hotel demand. Average duration of stay was 3.3 days in 2006, which represented a 1.3 times increase in hotel demand in the decade. The average duration of stay in terms of the number of days was obtained by the number of departures/ the number of arrivals.

Next, although the category of room or apartment rentals accounted for less than $10 \%$ of the total accommodation demand, about two thirds of the demand for this type of facility was concentrated in the north (Table 3 ). On the other hand, although central Italy accounted for $26.9 \%$ of the share, the rate of increase tripled in the last decade, and was especially high in Tuscany (3.4 times increase).

Agritourism in central Italy accounted for $51.8 \%$ of the total agritourism demand in terms of departures; in particular, Tuscany's share was more than one third, confirming the regional concentration of agritourism in central Italy as observed for the supply side (Table 4). The rate of demand increase in agritourism grew 4.8 times during the last decade, which was greater than the supply side increase and increase in demand for other accommodations. The increase in the south was greatest, at nine times. Nevertheless, share of the total accommodation demand by agritourism was less than $2 \%$ in Table 1 , which means that agritourism demand is still at the marginal stage. The mean duration 
Table 2: $\quad$ Change in demand for type of accommodation and region from 1997 to 2006 (hotel).

\begin{tabular}{|c|c|c|c|c|c|c|}
\hline $\begin{array}{c}\text { Type of } \\
\text { accommodation }\end{array}$ & Region & Category & 1997 & 2006 & $\begin{array}{c}06 / 97 \\
\text { ratio }\end{array}$ & $\begin{array}{c}* \text { Regional share } \\
\text { in } 2006(\%)\end{array}$ \\
\hline \multirow{11}{*}{ Hotel } & & No. arrivals & $32,060,852$ & $40,024,174$ & 1.2 & \multirow[b]{2}{*}{53.9} \\
\hline & North & $\begin{array}{l}\text { Mean duration } \\
\text { of stay }\end{array}$ & 3.8 & 3.4 & 0.9 & \\
\hline & \multirow{2}{*}{$\begin{array}{l}\text { Central } \\
\text { Italy }\end{array}$} & No. arrivals & $16,940,356$ & $22,229,719$ & 1.3 & \multirow[b]{2}{*}{24.8} \\
\hline & & $\begin{array}{l}\text { Mean duration } \\
\text { of stay }\end{array}$ & 2.7 & 2.8 & 1.0 & \\
\hline & & No. arrivals & $6,930,848$ & $8,152,334$ & 1.2 & \multirow[b]{2}{*}{8.9} \\
\hline & Tuscany & $\begin{array}{c}\text { Mean duration } \\
\text { of stay }\end{array}$ & 2.8 & 2.8 & 1.0 & \\
\hline & \multirow{3}{*}{ South } & No. arrivals & $11,063,543$ & $14,725,818$ & 1.3 & \multirow[b]{2}{*}{21.3} \\
\hline & & $\begin{array}{l}\text { Mean duration } \\
\text { of stay }\end{array}$ & 3.6 & 3.6 & 1.0 & \\
\hline & & No. arrivals & $60,064,751$ & $76,979,711$ & 1.3 & \multirow[b]{2}{*}{100.0} \\
\hline & Whole Italy & $\begin{array}{l}\text { Mean duration } \\
\text { of stay }\end{array}$ & 3.5 & 3.3 & 0.9 & \\
\hline & $\begin{array}{l}\% \text { share of } \\
\text { this type }\end{array}$ & No. departures & - & 68.1 & - & - \\
\hline
\end{tabular}

Source: Annuario Statistico Italiano, ISTAT

Note: * indictes the regional share in terms of no. of departures in 2006.

Table 3: $\quad$ Change in demand for type of accommodation and region from 1997 to 2006 (room rentals).

\begin{tabular}{|c|c|c|c|c|c|c|}
\hline $\begin{array}{c}\text { Type of } \\
\text { accommodation }\end{array}$ & Region & Category & 1997 & 2006 & $\begin{array}{l}06 / 97 \\
\text { ratio }\end{array}$ & $\begin{array}{l}\text { *Regional share } \\
\text { in } 2006(\%)\end{array}$ \\
\hline \multirow{11}{*}{$\begin{array}{l}\text { Room/apartment } \\
\text { rentals }\end{array}$} & \multirow[b]{2}{*}{ North } & No. arrivals & 954,217 & $2,498,158$ & 2.6 & \multirow[b]{2}{*}{65.7} \\
\hline & & $\begin{array}{c}\text { Mean duration } \\
\text { of stay }\end{array}$ & 9.2 & 8.6 & 0.9 & \\
\hline & \multirow{2}{*}{$\begin{array}{l}\text { Central } \\
\text { Italy }\end{array}$} & No. arrivals & 418,874 & $1,254,662$ & 3.0 & \multirow[b]{2}{*}{26.9} \\
\hline & & $\begin{array}{l}\text { Mean duration } \\
\text { of stay }\end{array}$ & 12.0 & 7.0 & 0.6 & \\
\hline & \multirow[b]{2}{*}{ Tuscany } & No. arrivals & 250,555 & 842,581 & 3.4 & \multirow[b]{2}{*}{15.3} \\
\hline & & $\begin{array}{c}\text { Mean duration } \\
\text { of stay }\end{array}$ & 8.8 & 5.9 & 0.7 & \\
\hline & \multirow{3}{*}{ South } & No. arrivals & 188,280 & 342,783 & 1.8 & \multirow[b]{2}{*}{7.4} \\
\hline & & $\begin{array}{l}\text { Mean duration } \\
\text { of stay }\end{array}$ & 8.6 & 7.1 & 0.8 & \\
\hline & & No. arrivals & $1,561,371$ & $4,095,603$ & 2.6 & \multirow[b]{2}{*}{100.0} \\
\hline & Whole Italy & $\begin{array}{c}\text { Mean duration } \\
\text { of stay }\end{array}$ & 9.9 & 8.0 & 0.8 & \\
\hline & $\begin{array}{c}\% \text { share of } \\
\text { this type }\end{array}$ & No. departures & - & 8.8 & - & - \\
\hline
\end{tabular}

Source: Annuario Statistico Italiano, ISTAT

Note: * indictes the regional share in terms of no. of departures in 2006. 
Table 4: $\quad$ Change in demand for type of accommodation and region from 1997 to 2006 (agritourism).

\begin{tabular}{|c|c|c|c|c|c|c|}
\hline $\begin{array}{c}\text { Type of } \\
\text { accommodation }\end{array}$ & Region & Category & 1997 & 2006 & $\begin{array}{l}06 / 97 \\
\text { ratio }\end{array}$ & $\begin{array}{c}* \text { Regional share } \\
\text { in } 2006(\%)\end{array}$ \\
\hline \multirow{11}{*}{ Agritourism } & & No. arrivals & 124,109 & 540,942 & 4.4 & \multirow[b]{2}{*}{37.2} \\
\hline & North & $\begin{array}{c}\text { Mean duration } \\
\text { of stay }\end{array}$ & 6.5 & 4.9 & 0.8 & \\
\hline & & No. arrivals & 224,948 & 747,009 & 3.3 & \multirow[b]{2}{*}{51.8} \\
\hline & Central Italy & $\begin{array}{c}\text { Mean duration } \\
\text { of stay }\end{array}$ & 5.6 & 5.0 & 0.9 & \\
\hline & & No. arrivals & 140,434 & 493,654 & 3.5 & \multirow[b]{2}{*}{36.6} \\
\hline & Tuscany & $\begin{array}{c}\text { Mean duration } \\
\text { of stay }\end{array}$ & 6.1 & 5.3 & 0.9 & \\
\hline & & No. arrivals & 23,861 & 214,181 & 9.0 & \multirow[b]{2}{*}{11.0} \\
\hline & South & $\begin{array}{c}\text { Mean duration } \\
\text { of stay }\end{array}$ & 7.0 & 3.7 & 0.5 & \\
\hline & & No. arrivals & 372,918 & $1,502,132$ & 4.0 & \multirow[b]{2}{*}{100.0} \\
\hline & Whole Italy & $\begin{array}{l}\text { Mean duration } \\
\text { of stay }\end{array}$ & 6.0 & 4.8 & 0.8 & \\
\hline & $\begin{array}{l}\% \text { share of } \\
\text { this type }\end{array}$ & No. departures & - & 1.9 & - & - \\
\hline
\end{tabular}

Source: Annuario Statistico Italiano, ISTAT

Note: * indictes the regional share in terms of no. of departures in 2006.

of stays in agritourism accommodations shortened from 6.0 to 4.8 days in the decade. In short, we can say that the demand pattern in agritourism differed from the traditional hotel demand pattern. Does the cause of this rapid demand increase in agritourism represent an increase in inbound tourists or in domestic tourists? This point is vital to clarify the demand structure of agritourism in Italy.

To approach this aim, first, we look at the trend of domestic tourism. Table 5 shows the share of domestic tourists according to accommodation facilities in terms of number of departures. Domestic demand accounted for more than half of the demand in hotel and non-hotel facilities in 2006 (hotels 56.3\%, non-hotels $58.7 \%$ ). Thus, we can say that Italian accommodation demand consists of two major markets: domestic and inbound markets. In the case of agritourism, the share of domestic tourists increased from $44.9 \%$ to $50.1 \%$ in the last decade, indicating growth in the domestic market.

From the viewpoint of domestic tourists, two thirds of domestic tourists chose to stay in hotels $(67.2 \%)$ and the remaining one third in non-hotel facilities $(32.8 \%)$, which clearly exhibits Italian's national preference for hotels (Table 6). In contrast, although the domestic demand for agritourism grew 3.6 times in the decade, only $1.7 \%$ of Italian tourists, a very tiny portion, stayed in this type of accommodation. Italian tourists stayed in hotels an average of 3.3 days and in agritourism facilities an average of 3.9 days, which is less than half of the duration for room or apartment rentals (9.2 days). In any case, the duration of stay is getting shorter in every category of accommodation. 
Table 5: Percentage facility-wise share of type of accommodation among domestic tourists.

\begin{tabular}{cccccc}
\hline Year & Four-five stars & Three stars & Two stars & Hotel total & - \\
\hline 1997 & 44.2 & 61.7 & 67.0 & 58.9 & - \\
2006 & 46.2 & 61.3 & 62.0 & 56.3 & - \\
$06 / 97$ ratio & 1.04 & 0.99 & 0.93 & 0.96 & - \\
\hline \multirow{2}{*}{ Year } & \multirow{2}{*}{ Camping site } & Room/apartment & \multirow{2}{*}{ Agritourism } & Non-hotel & \multirow{2}{*}{ total } \\
\hline 1997 & 59.9 & 55.0 & 44.9 & 61.0 & 59.5 \\
2006 & 57.9 & 56.6 & 50.1 & 58.7 & 57.0 \\
$06 / 97$ ratio & 0.97 & 1.03 & 1.12 & 0.96 & 0.96 \\
\hline
\end{tabular}

Source: Annuario Statistico Italiano, ISTAT

No: all figures are $\%$ share in terms of no. of departures.

Table 6: Domestic tourism demand in Italy.

\begin{tabular}{|c|c|c|c|c|c|c|c|}
\hline \multirow[b]{2}{*}{ Category } & \multicolumn{3}{|c|}{ Hotel } & \multicolumn{4}{|c|}{ Non-hotel } \\
\hline & $\begin{array}{l}\text { Four- } \\
\text { five }\end{array}$ & $\begin{array}{l}\text { Three } \\
\text { stars }\end{array}$ & $\begin{array}{r}\text { Hotel } \\
\text { total }\end{array}$ & $\begin{array}{c}\begin{array}{c}\text { Camping } \\
\text { site }\end{array} \\
\end{array}$ & $\begin{array}{l}\text { Room/apart- } \\
\text { ment rental }\end{array}$ & $\begin{array}{c}\text { Agri- } \\
\text { tourism }\end{array}$ & $\begin{array}{l}\text { Non- } \\
\text { hotel }\end{array}$ \\
\hline $\begin{array}{c}\text { Total no. departures } \\
(10,000 \text { people in } 2006)\end{array}$ & 3,929 & 8,123 & 14,178 & 3,645 & 1,852 & 3,610 & 6,935 \\
\hline $\begin{array}{l}\% \text { share of type of } \\
\text { accommodation* }\end{array}$ & 18.6 & 38.5 & 67.2 & 17.3 & 8.8 & 1.7 & 32.8 \\
\hline 06/97 ratio & 1.8 & 1.3 & 1.2 & 1.1 & 2.2 & 3.6 & 1.3 \\
\hline Mean duration of stay & 2.7 & 3.6 & 3.3 & 8.4 & 9.2 & 3.9 & 7.5 \\
\hline $06 / 97$ ratio & 1.1 & 1.0 & 0.9 & 0.9 & 0.8 & 0.8 & 0.8 \\
\hline
\end{tabular}

Source: Annuario Statistico Italiano, ISTAT

Note: *indicates $\%$ share of type of accommodation in terms of no. of departures.

\subsubsection{Inbound demand}

Here we examined inbound tourists nation-wise. Generally, the number of those tourists who stayed in agritourism facilities from European countries increased, although the duration of stay shortened. Especially, the number of departures remarkably increased more than that of arrivals from UK, Germany, Belgium, Ireland, The Netherlands and the Scandinavian countries. In addition to those from European countries, there was an upward trend in inbound tourists from North America, Oceania and Israel. Given the overall inbound trends noted above, we specifically focused on those countries that sent a large number of inbound tourists to Italy.

First, we could recognize large differences in the demand patterns from one main country to another. According to Table 7, German tourists, in comparison with those from The Netherlands, accounted for the most inbound tourists to Italy, stayed more often in hotels than non-hotels at a 6:4 ratio, stayed in 
Table 7: $\quad$ Inbound tourism demand in Italy (Germany and The Netherlands).

\begin{tabular}{|c|c|c|c|c|c|c|c|c|}
\hline \multirow[b]{2}{*}{ Country } & \multirow[b]{2}{*}{ Category } & \multicolumn{3}{|c|}{ Hotel } & \multicolumn{4}{|c|}{ Non-hotel } \\
\hline & & $\begin{array}{c}\text { Four- } \\
\text { five }\end{array}$ & $\begin{array}{c}\text { Three } \\
\text { stars }\end{array}$ & $\begin{array}{c}\text { Hotel } \\
\text { total }\end{array}$ & $\begin{array}{c}\text { Camping } \\
\text { site }\end{array}$ & $\begin{array}{c}\text { Room/apart- } \\
\text { ment rental }\end{array}$ & $\begin{array}{c}\text { Agri- } \\
\text { tourism }\end{array}$ & $\begin{array}{l}\text { Non- } \\
\text { hotel }\end{array}$ \\
\hline \multirow{5}{*}{ Germany } & $\begin{array}{c}\text { Total no. departures } \\
(10,000 \text { people in } 2006)\end{array}$ & 746 & 1,664 & 3,009 & 1,111 & 495 & 162 & 1,837 \\
\hline & $\begin{array}{l}\% \text { share of type of } \\
\text { accommodation* }\end{array}$ & 15.4 & 34.3 & 62.1 & 22.9 & 10.2 & 3.3 & 37.9 \\
\hline & 06/97 ratio & 1.3 & 1.0 & 0.9 & 1.0 & 1.3 & 2.1 & 1.1 \\
\hline & Mean duration of stay & 4.2 & 4.8 & 4.6 & 7.3 & 8 & 6.8 & 7.1 \\
\hline & 06/97 ratio & 1.0 & 1.0 & 1.0 & 1.0 & 0.9 & 0.9 & 1.0 \\
\hline \multirow{5}{*}{$\begin{array}{l}\text { The } \\
\text { Netherlands }\end{array}$} & $\begin{array}{r}\text { Total no. departures } \\
(10,000 \text { people in } 2006)\end{array}$ & 67 & 141 & 244 & 524 & 56 & 27 & 615 \\
\hline & $\begin{array}{l}\% \text { share of type of } \\
\text { accommodation* }\end{array}$ & 7.7 & 16.4 & 28.4 & 61.0 & 6.6 & 3.1 & 71.6 \\
\hline & 06/97 ratio & 2.1 & 1.6 & 1.6 & 2.0 & 2.9 & 4.7 & 2.1 \\
\hline & Mean duration of stay & 2.9 & 3.7 & 3.4 & 8.9 & 7.6 & 6.7 & 8.4 \\
\hline & $06 / 97$ ratio & 1.0 & 0.9 & 1.0 & 1.1 & 0.8 & 0.9 & 1.1 \\
\hline
\end{tabular}

Source: Annuario Statistico Italiano, ISTAT

Note: *indicates \% share of type of accommodation in terms of no. of departures.

agritourism facilities at a low rate (3.3\%) and stayed for about one week $(6.8$ days), which is longer than stays by domestic tourists. Although not shown in the table, the pattern for tourists from Austria was quite similar to that for the Germans. Conversely, the majority of Dutch tourists, over $70 \%$, stayed in nonhotels. In particular, more than $60 \%$ of Dutch tourists stayed in camping sites, contrasting sharply with patterns of domestic and German tourists. Because these accommodations are inexpensive, Dutch tourists stayed longer than tourists from any other countries (average of more than 8 days). The number of Dutch tourists who stayed in non-hotel accommodations more than doubled in the last decade. Among them, agritourism took a 3\% share of the Dutch tourists, with an increase of 4.7 times from the previous decade. In short, these traits are reflected in the method of travel, since the Dutch often drive down to Italy in motor homes or by automobile. Those tourists from northern European countries come down to the sunny south in summer and tend to stay longer.

On the other hand, tourists from neighboring Mediterranean Latin countries such as France, Spain, Greece, and Portugal prefer hotels to non-hotels more than tourists from northern Europe while the rates of increase in those tourists who went to agritourism facilities were higher than those who used other types of accommodation (Table 8). Among former socialist Eastern European countries, a relatively higher portion of inbound tourists stayed in apartments that enable tourists to cook for themselves and are less expensive than other facilities (Table 9). Likewise, similar characteristics were observed in tourists from other Eastern European countries, such as from Poland, Hungary, Croatia and Slovenia. 
Table 8: $\quad$ Inbound tourism demand in Italy (France and Spain).

\begin{tabular}{|c|c|c|c|c|c|c|c|c|}
\hline \multirow[b]{2}{*}{ Country } & \multirow[b]{2}{*}{ Category } & \multicolumn{3}{|c|}{ Hotel } & \multicolumn{4}{|c|}{ Non-hotel } \\
\hline & & $\begin{array}{l}\text { Four- } \\
\text { five }\end{array}$ & $\begin{array}{l}\text { Three } \\
\text { stars }\end{array}$ & $\begin{array}{c}\text { Hotel } \\
\text { total }\end{array}$ & $\begin{array}{l}\text { Camping } \\
\text { site }\end{array}$ & $\begin{array}{l}\text { Room/apart- } \\
\text { ment rental }\end{array}$ & $\begin{array}{l}\text { Agri- } \\
\text { tourism }\end{array}$ & $\begin{array}{l}\text { Non- } \\
\text { hotel }\end{array}$ \\
\hline \multirow{5}{*}{ France } & $\begin{array}{r}\text { Total no. departures } \\
(10,000 \text { people in } 2006)\end{array}$ & 197 & 385 & 674 & 120 & 54 & 21 & 233 \\
\hline & $\begin{array}{l}\% \text { share of type of } \\
\text { accommodation* }\end{array}$ & 21.7 & 42.4 & 74.3 & 13.3 & 5.9 & 2.3 & 25.7 \\
\hline & $06 / 97$ ratio & 1.8 & 1.3 & 1.4 & 1.3 & 4.7 & 4.6 & 1.8 \\
\hline & Mean duration of stay & 2.6 & 3.1 & 2.9 & 4.8 & 5.1 & 5.6 & 4.4 \\
\hline & $06 / 97$ ratio & 1.0 & 1.0 & 1.0 & 0.9 & 0.7 & 0.9 & 0.9 \\
\hline \multirow{5}{*}{ Spain } & $\begin{array}{r}\text { Total no. departures } \\
(10,000 \text { people in } 2006)\end{array}$ & 108 & 118 & 245 & 18 & 16 & 3 & 54 \\
\hline & $\begin{array}{l}\% \text { share of type of } \\
\text { accommodation* }\end{array}$ & 36.2 & 39.5 & 81.8 & 6.1 & 5.3 & 1.1 & 18.2 \\
\hline & $06 / 97$ ratio & 3.1 & 2.0 & 2.4 & 1.4 & 7.3 & 8.7 & 2.7 \\
\hline & Mean duration of stay & 2.1 & 2.4 & 2.3 & 3.4 & 3.7 & 4.5 & 3.3 \\
\hline & $06 / 97$ ratio & 1.0 & 1.0 & 1.0 & 0.9 & 0.5 & 0.9 & 1.0 \\
\hline
\end{tabular}

Source: Annuario Statistico Italiano, ISTAT

Note: *indicates $\%$ share of type of accommodation in terms of no. of departures.

Table 9: $\quad$ Inbound tourism demand in Italy (Czech Republic and Russia).

\begin{tabular}{|c|c|c|c|c|c|c|c|c|}
\hline \multirow[b]{2}{*}{ Country } & \multirow[b]{2}{*}{ Category } & \multicolumn{3}{|c|}{ Hotel } & \multicolumn{4}{|c|}{ Non-hotel } \\
\hline & & $\begin{array}{l}\begin{array}{l}\text { Four- } \\
\text { five }\end{array} \\
\end{array}$ & $\begin{array}{c}\begin{array}{c}\text { Three } \\
\text { stars }\end{array} \\
\end{array}$ & $\begin{array}{c}\begin{array}{c}\text { Hotel } \\
\text { total }\end{array} \\
\end{array}$ & $\begin{array}{l}\text { Camping } \\
\text { site } \\
\end{array}$ & $\begin{array}{c}\text { Room/apart- } \\
\text { ment rental }\end{array}$ & $\begin{array}{c}\text { Agri- } \\
\text { tourism }\end{array}$ & $\begin{array}{l}\text { Non- } \\
\text { hotel }\end{array}$ \\
\hline \multirow{5}{*}{$\begin{array}{l}\text { Czech } \\
\text { republic }\end{array}$} & $\begin{array}{r}\text { Total no. departures } \\
(10,000 \text { people in } 2006)\end{array}$ & 13 & 62 & 96 & 43 & 70 & 2 & 121 \\
\hline & $\begin{array}{l}\% \text { share of type of } \\
\text { accommodation* }\end{array}$ & 6.2 & 28.6 & 44.2 & 19.8 & 32.4 & 0.8 & 55.8 \\
\hline & 06/97 ratio & 4.0 & 4.3 & 3.0 & 1.1 & 4.3 & 6.2 & 2.0 \\
\hline & Mean duration of stay & 3.1 & 4.6 & 4.2 & 6.0 & 7.9 & 6.0 & 6.7 \\
\hline & 06/97 ratio & 1.0 & 1.3 & 1.1 & 0.9 & 0.9 & 0.6 & 1.0 \\
\hline \multirow{5}{*}{ Russia } & $\begin{array}{r}\text { Total no. departures } \\
(10,000 \text { people in } 2006)\end{array}$ & 122 & 109 & 244 & 5 & 8 & 1 & 18 \\
\hline & $\begin{array}{l}\% \text { share of type of } \\
\text { accommodation* }\end{array}$ & 46.6 & 41.6 & 93.2 & 1.7 & 3.1 & 0.2 & 6.8 \\
\hline & 06/97 ratio & 3.0 & 1.4 & 1.8 & 1.4 & 2.8 & 3.2 & 1.8 \\
\hline & Mean duration of stay & 3.9 & 3.2 & 3.5 & 5.6 & 8.0 & 4.9 & 6.8 \\
\hline & 06/97 ratio & 1.0 & 0.8 & 0.9 & 0.9 & 0.7 & 0.5 & 0.8 \\
\hline
\end{tabular}

Source: Annuario Statistico Italiano, ISTAT

Note: *indicates $\%$ share of type of accommodation in terms of no. of departures.

In contrast, over $90 \%$ of Russian tourists stayed in hotels although agritourism showed the highest growth rate among types of accommodations (Table 9).

British tourists, separated by water although a tunnel exists, definitely prefer to stay in hotels; more than $80 \%$ stay in hotels and less than $20 \%$ in non-hotels (Table 10). Because of this preference for hotels, the length of stay was 5.5 days on average in non-hotels, which is much shorter than for the Dutch, with a 
preference for economical accommodations. Again, agritourism's share of British tourists was very low but the rate of increase in the decade was high, by nearly three times.

Now, going beyond Europe, tourists from USA acted similarly to the British tourists, with a strong preference for hotels, but with a shorter stay: about 4 days on average in non-hotels. Demand patterns for agritourism accommodations and apartments were similar to those of other countries.

Among Asian countries, those Japanese tourists who stayed in non-hotels were exceptional because $96 \%$ of Japanese stayed in hotels (Table 11). Another distinctive trait is a very short visit, an average of about 3 days even in nonhotels. Their busy tour schedule was reflected in this demand pattern. Although the demand for non-hotels is rising, the number of tourists who stayed in nonhotels including agritourism facilities, is still at the negligible stage. This is probably because tourists from this region have a higher preference for urban tourism such as visiting cultural heritage sites and shopping in the city rather than agritourism in rural areas.

Although outbound tourism in China is growing rapidly with a huge potential (Guo et al. [4]), still the number of inbound tourists is only one third of that from Japan (Table 11). Their preference for hotels was similar to that of Japanese: $95 \%$ of accommodation demand was for hotels. By the same token, the demand for agritourism increased 16 times, but the number of tourists was still very small. Although there is not a table showing statistics for the Korean case, we can observe the same pattern for city tourism, which is a common feature among Asian tourists.

Table 10: $\quad$ Inbound tourism demand in Italy (UK and USA).

\begin{tabular}{|c|c|c|c|c|c|c|c|c|}
\hline \multirow[b]{2}{*}{ Country } & \multirow[b]{2}{*}{ Category } & \multicolumn{3}{|c|}{ Hotel } & \multicolumn{4}{|c|}{ Non-hotel } \\
\hline & & $\begin{array}{l}\text { Four- } \\
\text { five }\end{array}$ & $\begin{array}{l}\text { Three } \\
\text { stars }\end{array}$ & $\begin{array}{c}\text { Hotel } \\
\text { total }\end{array}$ & $\begin{array}{l}\text { Camping } \\
\text { site }\end{array}$ & $\begin{array}{l}\text { Room/apart- } \\
\text { ment rental }\end{array}$ & $\begin{array}{l}\text { Agri- } \\
\text { tourism }\end{array}$ & $\begin{array}{l}\text { Non- } \\
\text { hotel }\end{array}$ \\
\hline \multirow{5}{*}{ UK } & $\begin{array}{r}\text { Total no. departures } \\
(10,000 \text { people in } 2006)\end{array}$ & 551 & 449 & 1,084 & 96 & 68 & 26 & 220 \\
\hline & $\begin{array}{l}\% \text { share of type of } \\
\text { accommodation* }\end{array}$ & 42.3 & 34.4 & 83.1 & 7.4 & 5.2 & 2.0 & 16.9 \\
\hline & 06/97 ratio & 2.1 & 1.6 & 1.7 & 1.2 & 3.4 & 2.9 & 1.9 \\
\hline & Mean duration of stay & 3.6 & 4.0 & 3.8 & 6.6 & 5.1 & 6.5 & 5.5 \\
\hline & 06/97 ratio & 1.0 & 0.9 & 1.0 & 0.8 & 0.6 & 0.9 & 0.8 \\
\hline \multirow{5}{*}{ USA } & $\begin{array}{r}\text { Total no. departures } \\
(10,000 \text { people in } 2004)\end{array}$ & 519 & 294 & 903 & 19 & 61 & 17 & 139 \\
\hline & $\begin{array}{l}\% \text { share of type of } \\
\text { accommodation* }\end{array}$ & 49.8 & 28.2 & 86.7 & 1.8 & 5.9 & 1.6 & 13.3 \\
\hline & 04/97 ratio & 1.3 & 1.2 & 1.2 & 0.8 & 3.5 & 3.1 & 2.3 \\
\hline & Mean duration of stay & 2.4 & 2.4 & 2.4 & 5.0 & 4.1 & 4.7 & 4.1 \\
\hline & 04/97 ratio & 1.1 & 0.9 & 1.0 & 0.6 & 0.6 & 0.8 & 0.8 \\
\hline
\end{tabular}

Source: Annuario Statistico Italiano, ISTAT

Note: *indicates \% share of type of accommodation in terms of no. of departures. 
Table 11: Inbound tourism demand in Italy (Japan and China).

\begin{tabular}{|c|c|c|c|c|c|c|c|c|}
\hline \multirow[b]{2}{*}{ Country } & \multirow[b]{2}{*}{ Category } & \multicolumn{3}{|c|}{ Hotel } & \multicolumn{4}{|c|}{ Non-hotel } \\
\hline & & $\begin{array}{l}\text { Four- } \\
\text { five }\end{array}$ & $\begin{array}{c}\text { Three } \\
\text { stars }\end{array}$ & $\begin{array}{c}\text { Hotel } \\
\text { total }\end{array}$ & $\begin{array}{l}\text { Camping } \\
\text { site }\end{array}$ & $\begin{array}{l}\text { Room/apart- } \\
\text { ment rental }\end{array}$ & $\begin{array}{l}\text { Agri- } \\
\text { tourism }\end{array}$ & $\begin{array}{l}\text { Non- } \\
\text { hotel }\end{array}$ \\
\hline \multirow{5}{*}{ Japan } & $\begin{array}{c}\text { Total no. departures } \\
(10,000 \text { people in } 2004)\end{array}$ & 246 & 71 & 331 & 2 & 6 & 0.5 & 13 \\
\hline & $\begin{array}{l}\% \text { share of type of } \\
\text { accommodation* }\end{array}$ & 71.4 & 20.6 & 96.2 & 0.6 & 1.6 & 0.2 & 3.8 \\
\hline & 04/97 ratio & 0.8 & 0.7 & 0.8 & 0.8 & 2.2 & 2.4 & 1.3 \\
\hline & Mean duration of stay & 2.0 & 2.0 & 2.0 & 7.8 & 3.1 & 3.3 & 3.2 \\
\hline & 04/97 ratio & 1.0 & 0.9 & 1.0 & 0.8 & 0.7 & 0.8 & 1.0 \\
\hline \multirow{5}{*}{ China } & $\begin{array}{c}\text { Total no. departures } \\
(10,000 \text { people in } 2004)\end{array}$ & 79 & 36 & 122 & 1 & 3 & 0.2 & 7 \\
\hline & $\begin{array}{l}\% \text { share of type of } \\
\text { accommodation* }\end{array}$ & 61.0 & 27.9 & 94.6 & 0.4 & 2.6 & 0.2 & 5.4 \\
\hline & 04/97 ratio & 8.7 & 6.7 & 7.2 & 5.3 & 9.0 & 16.1 & 9.2 \\
\hline & Mean duration of stay & 1.6 & 1.8 & 1.7 & 3.2 & 6.6 & 7.9 & 5.0 \\
\hline & 04/97 ratio & 1.2 & 0.7 & 1.0 & 0.6 & 0.6 & 1.3 & 1.0 \\
\hline
\end{tabular}

Source: Annuario Statistico Italiano, ISTAT

Note: *indicates $\%$ share of type of accommodation in terms of no. of departures.

To conclude, while the preference for accommodations differed from country to another, it was commonly observed that the number of inbound tourists to agritourism facilities increased at a higher rate than to other types of accommodations in every country. Finally, it should be noted that the agritourism market in Italy has two main pillars for its growth: domestic and inbound tourists from European countries.

\section{Conclusions}

This paper mainly focused on the demand trend of the agritourism in Italy. Main findings are as follows:

(1) The number of beds available and tourists who stayed in agritourism facilities increased more rapidly in the last decade than for other type of facilities.

(2) Regionally, central Italy takes the largest share of agritourism while the increase in demand in the late starter south was equally large.

(3) The agritourism market has two major engines for demand growth: domestic and inbound demand. European tourists comprise the majority of this inbound demand due to the special factors that reduce barriers to tourism in European countries such as the availability of similarly developed surrounding countries, surface transportation, the introduction of common currency free from exchange risks and so on. Even if these favorable conditions are considered, in addition to the domestic demand, this fact suggests the significance of inbound demand for development of agritourism. Especially, neighboring countries are a promising demand pool to be explored. Thus, this aspect should be well taken into account in the marketing strategy for agritourism. 


\section{References}

[1] Baloglu, S. \& Mangaloglu M., Tourism destination Images of Turkey, Egypt, Greece, and Italy as perceived by US-based tour operators and travel agents. Tourism Management, 22, pp.1-9, 2001.

[2] Baloglu, S. \& McCleary, K.W., U.S. International pleasure travelers' images of four Mediterranean destinations: A comparison of visitors and nonvisitors. Journal of Travel Research, 38, pp.144-152, 1999.

[3] Getz, D. \& Brown, G., Linking wine preferences to the choice of wine tourism destinations. Journal of Travel Research, 43, pp.266-276, 2005.

[4] Guo, Y., Kim, S. S. \& Timothy, D. J., Development characteristics and implications of mainland Chinese outbound tourism. Asian Pacific Journal of Tourism Research, 12(4), pp.313-332, 2007.

[5] ISTAT, Annuario Statistico Italiano, ISTAT: Rome, pp. 444-461, 1998.

[6] Mazzocchi, M. and Montini, A., Earthquake effects on tourism in Central Italy. Annals of Tourism Research, 28(4), pp.1031-1046, 2001.

[7] Ohe, Y. \& Ciani, A., The activity and characteristics of agri-tourism farms: A study of Umbria, Italy. The Bulletin of the Chugoku National Agricultural Experiment Station, 19, pp.1-18, 1998.

[8] Ohe, Y. \& Ciani, A., Evolutionary process of agri-tourism in Central Italy, Umbria. Japanese Journal of Tourism Research, 2, pp.11-18, 2003.

[9] Ohe, Y. \& Ciani, A., Evaluating diversification of rural tourism: A case of Umbria, Italy. Japanese Journal of Farm Management, 43(1), pp.124-127, 2005.

[10] Peypoch, N., On measuring tourism productivity. Asian Pacific Journal of Tourism Research, 12(3), pp.237-244, 2007.

[11] Velázquez, B. E., Agritourism in Italy, in OECD, Multifunctionality in Agriculture: What Role for Private Initiatives? OECD: Paris, pp.35-40, 2005. 